\title{
The American Historical Association: U.S. and European Labor History
}

\author{
Sven Beckert and Patrick Young \\ Columbia University
}

Working-class history was not a central theme at the December 1990 meeting of the American Historical Assocation. Few panels dealt exclusively with labor, and those which did were often organized by affiliated organizations, not by the AHA. At the center of the debates that did take place was the impact of gender and ethnicity on working-class formation, thereby reaffirming the by-now welldeveloped connections between women, immigration, and labor history. Unfortunately, many papers had lost sight of such important issues as class relations, capital formation, or politics, sometimes resulting in a dehistorization of the very issues so central to the current debates.

One of the most interesting and conceptually innovative papers was presented by Tera W. Hunter on "Afro-American Women Household Workers' Resistance in the New South." She found a wide variety of household workers' resistance, ranging from the appropriation of their employers' assets to well-organized strikes. The black women's strength derived from tightly knit communities and, as in the case of washerwomen, from collective work settings. Rebuking many widely held assumptions about the character of black migrant workers in the North, Hunter showed convincingly that they often carried an experience of collective action with them. A similar point was made by Eric Arnesen in his paper on "Black Workers and Biracial Unions in the Age of Segregation." Looking closely at the unionization of southern dockworkers between 1880 and 1920, he explained the fluid and changing nature of biracial unionism through differences in the structure of labor markets. In New Orleans, for example, a highly competitive labor market forced black and white workers together, whereas in Galveston, Texas, segregation and a less competitive labor market resulted in separate unions. Although black workers faced a hostile labor movement, they did not retreat from it but instead were able to carve out a place of their own.

These creative approaches to the analysis of the conditions for unity and divisions in the working class were not entirely mirrored in a panel organized by the Polish American Historical Association on "Immigrant Labor History in Comparative Perspective: Poles and Italians in the Textile Mills of Central New York." James Pula's paper on "Corporate Capitalism and Immigrant Workers in the New York Mills Textile Strike of 1916" emphasized the fusion of ethnic culture and

International Labor and Working-Class History

No. 40, Fall 1991, pp. 103-115

(C) 1991 by the Board of Trustees of the University of Illinois 
class goals in producing a successful strike outcome, while Philip Bean, in his paper on "Italian Workers and Ethnic Rivalries in the Utica Textile Strike of 1919," argued that the latter failed because of ethnic conflicts, police repression, and the strikers' exhaustion. Cecilia Bucki and other commentators critiqued the lack of attention to larger changes in the political economy between 1916 and 1919. Moreover, Bucki urged historians to examine the process of the social construction of ethnicity.

In a panel on "Intersections and Collision Courses: Women, Blacks, and Workers Confront Gender, Race and Class," participants attempted to get beyond the idea that historians must simply pay attention to all diversity. Elsa Barkley Brown argued for more than inclusion of these categories in historical writing and instead urged attention to the interplay between them. Nancy Hewitt highlighted criticisms of the "Trinity" of gender, race, and class, noting that this model has directed attention only to subordinated groups, not to the question of how these categories affect dominant groups. She called for a reformulation of the model in order to redress problems.

In a panel entitled, "Women Working with Women: Class, Gender, and Race in British Religion, 1790-1940," Deborah Valenze and Jeffrey Cox explored the complexities and contradictions of middle-class women's work in two separate contexts. Valenze, relying primarily upon a close reading of the novels of Hannah More, argued that the peculiar identity of female charity workers derived less from religious doctrine than from the need to clearly demarcate and maintain boundaries with other classes. The virtue, diligence, and shrewdness of More's characters, Valenze suggested, reveal both a suspicion of the moral character of seemingly idle aristocratic and working-class women, and a protofeminist challenging of restrictions on female work and identity. Cox focused on the missionary work of British women in Delhi and Lahore, arguing that women often found work opportunities in the imperial context that were denied them at home. Women often rose to positions of great influence in missionary hospitals and schools. Though successful in challenging gender distinctions, however, they failed to identify with their women patients: Orientalist racism and the increasing scale and impersonalism of women's missionary enterprises inhibited the development of such bonds of sympathy as did exist between women of the two cultures.

A panel on "Revolution, Radicals, and the Making of the Working Class" afforded a comparative, transatlantic perspective on the development of class consciousness. In his sweeping study of Philadelphia artisans of the eighteenth through the early twentieth centuries, Ron Schultz challenged the popular notion that worker involvement in parliamentary politics tended to blunt class consciousness. He suggested that the formation of the Workingmen's party in the $1820 \mathrm{~s}$ marked the culmination of a long process in which involvement in antiproprietary politics actually nurtured and focused the "moral" aspects of artisan experience. Iowerth Prothero, in his paper on artisan radicalism in pre-Reform England, warned of the dangers of unproblematically identifying radicalism with the work experience of the artisan. What unity did exist between workers, Prothero 
suggested, derived primarily from the sharing of political idioms and mutual participation in political institutions and campaigns; experience in the workshop more often served to divide than unite. Bernard Moss, meanwhile, criticized the now-standard "culturalist" approach to labor history in his account of the making of the French working class. Rather than identifying class consciousness and socialism as being continuous with earlier popular traditions, as such an approach mandates, Moss suggested them to be the product of a rupture. It was, he argued, the combined influence of proletarianization and interaction with middle-class socialists that allowed French workers to develop a rational, collective critique: the language of labor militants in 1848 was the language of middle-class socialism, not of corporatism or of any other indigenous working-class culture.

Sonya Rose and Mary Blewett led a session titled, "Gender Politics and Labor Activism: A Cross-Cultural Comparison," which dealt with the gendered construction of working-class identities in England and America. In her paper, Rose suggested the ways in which the masculine discourse of "respectable dissent" evolved by Lancashire textile workers of the 1870 s gendered class and marginalized women in union activity. The peculiarly violent and disruptive quality of women workers' protest activity, she argued, must be set in the cuntext of this rhetorical marginalization and understood as a contestation of masculine conceptions of class. Focusing on the textile workers of Fall River, Massachusetts, Mary Blewett found that women's participation in union activity, while still often confrontational, was more readily accepted by male workers across the Atlantic. She showed that women achieved a visible prominence in the 1875 strike of Fall River mule spinners and in fact succeeded in convincing their male comrades of the need for an older, more radical form of protest. The strike, Blewett concluded, marked a significant historical moment in which there existed the possibility of a more inclusive construction of class identity and hence of a more united and powerful labor movement.

William Smaldone, Joseph McCartin, and James Naylor discussed post World War I "Workers' Movements and the Debate Over Social Reconstruction." Smaldone suggested that labor's chances of significantly influencing reconstruction in Germany were compromised by rifts between leadership and rank and file, with the consequent failure to articulate a clear and consistent political perspective. Focusing on the writings of Rudolf Hilferding, a key USPD theorist, Smaldone linked the increasing fragmentation of postwar German socialism to the difficulties of reconciling socialist ideology with the imperatives of economic crisis, parliamentary participation, and right-wing resurgence. McCartin and Naylor explored the role played by, respectively, the American and Canadian working classes in reconstruction. In her comment, Mary Nolan noted the "top down" political approach of these papers and of much recent labor history and suggested that debates over reconstruction might be more successfully placed in the context of debates within the labor movement than in the context of national policy debates. 